\title{
Comparative Studies on Fungal Biodiversity of agricultural field soil from Thiruvannamalai District, Tamil Nadu, India
}

\author{
P. Jayaraman ${ }^{1 *}$, S. Shalini ${ }^{2}$, K. Saraswathi ${ }^{1}$, K. Vadamalai $^{1}$ and R. Logambal ${ }^{1}$ \\ ${ }^{1}$ Research Department of Botany, Government Arts College for Men (Autonomous), \\ Nandanam, Chennai 600 035, Tamil Nadu, India \\ ${ }^{2}$ Research Department of Botany, Government Arts College, Thiruvannamalai 606 603, \\ Tamil Nadu, India \\ *Corresponding author
}

\section{A B S T R A C T}

\section{Keywords}

Soil fungi, Fungal biodiversity, Agricultural soil, Rhizosphere mycoflora, Antifungal effect

Article Info

Accepted:

28 December 2017 Available Online: 10 July 2018

\begin{abstract}
Soil microorganisms such as bacteria and fungi play an important role in soil fertility and promoting the plant growth. Sixty soil samples are collected of different agricultural crop fields such as groundnut field, sugarcane field, Plantain field, turmeric field, tapioca field and wasteland with Parthenium field in and around Thiruvannamalai, Tamil Nadu were investigated soil moisture content by oven drying method and diversity of fungi by using serial dilution plating method with standard Potato Dextrose Agar (PDA) for qualitative and quantitative pattern. The moisture content of different soil samples collected from the above fields were found from $11.0 \%$ to $26.3 \%$. Among the soil samples, the groundnut and turmeric field show higher moisture as $26.0 \%$ and $26.3 \%$ and the lowest level was observed in sugarcane and tapioca soil with $11.0 \%$ and $17.0 \%$ respectively. For analysis of fungi, 22 species were enumerated from the above soil samples in which Aspergillus niger, A. flavus, A. terreus, A. fumigatus, Trichoderma spp., Cladosporium cladosporioides, Curvularia lunata, Gliocladium sp., Fusarium sp. and white non sporulating fungus were remarkably present. Regarding the distribution of occurrence, Plantain filed show highest as $28 \%$ followed by groundnut field with $23 \%$, Sugarcane field $17 \%$, Tapioca and waste land soil each with $14 \%$ and the turmeric field soil has the lowest occurrence as $4 \%$ of fungal population. It is concluded that from the present study as the turmeric field soil has an antimicrobial effect which shows very low population of fungi in their soil environment when compared with other soil samples.
\end{abstract}

\section{Introduction}

The relationship between biodiversity of soil fungi and function of ecosystem is an issue of paramount importance, particularly in the face of global climate change and human alteration ecosystem processes. Fungi are an important component of the soil micro- biota typically of soil biomass than bacteria depending on soil depth and nutrient condition such as micro and macro nutrients. The saprophytic fungi represent the largest proportion of fungal species in soil and they perform a crucial role in the decomposition of plant structural polymers, such as cellulose, hemicelluloses and lignin thus contributing carbon and 
nitrogen source to increase the fertility of soil (Breure 2004). Mostly the distribution of fungi in agricultural soils is prominent (Carney et al., 2006) and less is reported about the occurrence of fungi under natural soil condition. Soil microorganisms including fungi can have both positive and negative effects on plant growth and facilitate nutrient absorption by plants, promote plant growth or stimulate seedling development by producing hormone-like substances. Therefore, the soil is the most suitable environment and serves as a good culture medium for the growth of fungi. Generally, soils contain $10^{5}$ to $10^{6} \mathrm{cfu} / \mathrm{g}$ and 100 to $1500 \mathrm{~g}$ biomass per meter square. Some of the fungi have the ability to make rapid growth on organic substrates in dry, acid, coarse textured soil and thus to reach nutrients available to unicellular microorganisms by diffusion (Trinci, 1969; Ambikapathy et al., 1994).

There are many reports on biodiversity and influence of different species of fungi on various soil locations were available at global level which indicates the soil fungi are ubiquitous and inhabit different types of soils. From various reports, the fungi commonly present in different type of soils found as Aspergillus niger, A. flavus, A. clavatus, A. terreus, Curvularia lunata, Pencillium janthinellum, P. citrinum, Rhizopus nigricans, Trichoderma viride, T. harzianum, Fusarium. oxysporium, F. moniliforme, Mucor, Cladosporium, Verticillium, Acremonium, Chaetomium globosum, Corynespora cassicola, Eurotium chevelari, Botrycis cineea, Helminthosporium sp. etc. (Breure (2004); Mahmood Khalid et al., (2006); Falih (1997); (El-Said, 2001). Among the species of fungi reported in soil by various authors, the Aspergillus is the dominant genus followed by Penicillium species, several species of hyphomycetes and Zygomycetes are frequently occurring in various soil samples Falih (1997); Moallaei et al., 2006; Gauri
Rane et al., (2006); Gangawane and Despande (1972), Reddy et al., (1987), Saksena et. al. (1967), Manoharachary et al., (1990); (Guleri et. al. (2010); Suderma et al., (2011); Madhan Raj et al., (2010).

The study of population determinations of soil fungi from two different groundnut fields for three years period suggested that planting peanuts did not result in an increased A.flavus which may be able to colonize peanut fruits from low inoculum density levels (Gray et al., 1974). The investigation on the paddy field, the population of soil mycoflora was studied by Ambikapathy et al., (2001) found with 26 individual fungal species of fungi. Among the species of fungi isolated from peanut field, most of them were belonged to euteromycetes. Aspergillus, Penicillium and Fusarium were comparatively more than the other speices in most of the soil samples. In Sudan, the investigation of soil mycoflora of sugarcane field at Kenana sugar Estate was carried out and there are 23 species were isolated which are belonging to 16 genera and the richest taxa in abundance were Aspergillus spp., Penicillium sp., Rhizopus sp., Alternaria sp., Curvularia sp. and Fusarium sp. (Al-Nur ElAmin et al., (2007). During monsoon season, maximum fungal count was recorded in 20092010 and found dominant with species of Aspergillus niger, A. flavus, A. clavatus, Curvularia lunata, Bipolaris oryzae, Pencillium janthinellum, P. citrinum followed by Rhizopus nigricans, Trichoderma viride, $T$. harzianum from the paddy field were recorded (Manimegalai et al., (2011). Jayalakshmi and Valluva paridasan (2010) were investigated the fungus from Parthenium weed insfested soil. There are 13 fungal species were isolated, that are A. niger, A. flavus, A. fumigatus, Chatomium globosum, Corynospora cassicola, Curvularia lunata, Curvularia sp., Eurotium chavelari, Fusarium oxysporam, F. moniliforme, Monilia sp., Rhizpus Stolonifer and Trichoderma harizianum. Among this, A. 
niger and $R$. Stolonifer were found to be present throught Tamil Nadu. Both A.flavus and $T$. harizianum ranked next with an Equal distribution. Monilia sp. and Corynospora cassicola represented poor percentage distribution in Tamilnadu. However, the studies of fungal biodiversity in the rhizosphere of crop plants in agricultural soil and it interaction with micro-organisms is not sufficient to understand the mechanism of soil microbes. Suderma et al., (2011) have reported the fungi inhabitated in Banana field of the soil collected from Bali i.e. Karangasem, Klungkung and Jembrana which are main banana growing areas in which Streptomyces spp., Trichoderma spp., Aspergillus spp., Penicillium spp and Gliocladium spp are higher in the soil.

Therefore, the present study was undertaken to analyze the soil mycoflora of various agricultural field soil samples which are collected during the crop cultivation to know the seasonal relationship, effect of crop plants on the soil mycoflora and interaction between the soil ecosystem and other physiochemical parameters. The results are discussed in detail in the present study.

\section{Materials and Methods}

\section{Collection of soil samples}

The soil samples from groundnut field, sugarcane field, Plantain field, turmeric field, tapioca field and wasteland with Parthenium field were collected from Thiruvannamalai, Tamil Nadu at different locations within 15 $\mathrm{km}$ radius. In each field, $200 \mathrm{~g}$ soil samples were collected from 10 different places of the same field at $5-15 \mathrm{~cm}$ depth and pooled together to obtain composite sample. The soil samples were collected in pre-cleaned polythene bags cleaned with alcohol and labeled after collection. The samples were kept it in the laboratory for further analysis.

\section{Analysis of soil moisture}

The moisture content of the soil samples were determined by standard oven-drying method (Mishra, 1968). Exactly $1 \mathrm{~g}$ of freshly collected sample of soil was weighed in a preweighed empty glass Petri-dish. The petri-dish with soil sample was placed in a hot air oven for 2 hours at $105^{\circ} \mathrm{C}$. After drying, the soil sample of the petri-dish was cooled to room temperature and weighed for loss of weight. The initial and final weight of the Petri-dish with soil sample was determined to calculate the percentage of moisture content. The following standard formula was used for the calculation of moisture content percentage.

$\begin{array}{r}\text { Initial weight (Petridish with soil) }- \\ \text { Final weight }\end{array}$
$\begin{array}{r}\text { We of soil moisture } \\ \text { Weight of soil sample taken }\end{array}$

\section{Isolation of fungi from the soil samples}

The soil fungi were enumerated by Soil Dilution plating method (Walksman, 1922) on Potato Dextrose Agar (PDA) media and Johnson et al., (1960).

\section{Serial Dilution Plate method for Isolation of Fungi (Waksman, 1922)}

Exactly $10 \mathrm{~g}$ of soil sample was suspended in $90 \mathrm{ml}$ of sterile saline (1\%) water and kept it in shaker for $15 \mathrm{mins}$ and allowed to settle the soil particles. From each suspended sample to make microbial dilutions from $10^{-1}$ to $10^{-5}$, dilution of $10^{-2}, 10^{-3}$ and $10^{-4}$ were used to isolate fungi. About $1 \mathrm{ml}$ of microbial suspension of each concentration was added and spreaded on pre-plated sterile PDA medium by spread plate method. One percent streptomycin solution was used for an antibacterial. Sufficient duplicates in each dilution were maintained to avoid experimental error. The inoculated plates were 
incubated at $28^{\circ} \mathrm{C}$ for $5-7$ days. The plates were observed periodically everyday up to 7 days. The colony forming units (CFU) of the fungal isolates were calculated. All the results were calculated and statistical analysis was performed.

\section{Identification of Mycoflora in Soil}

The fungal colonies formed in the agar plates were observed for qualitative and quantitative pattern. The morphology of fungi was studied macroscopically by observing colony features such as texture and color. The hyphal structure, spore shapes and size, spore bearing structures were observed microscopically by staining with cotton blue under light microscope. The observations were compared with the standard works of Raper and Thom (1949), Van Ark (1974), Raper et al., (1965), Eills (1976) and Barnett and Hunter, (1998) for identification of the fungi at species level.

\section{Quantitative pattern of fungi}

The total number of fungal colonies present in the plates by using $1 \mathrm{~g}$ of soil from each sample was observed and calculated. The percent contribution of each isolate was calculated by using the following formula:

Total No. of CFU of an individual species $\%$ Contribution = -------------------------- X 100

Total No. of CFU of all species

*CFU-Colony forming Unit

\section{Results and Discussion}

\section{Details of sample collection}

The sample collection is an important role for the better analysis, also considered as a crop harvesting period which should cover within the sampling protocol. The details of soil sample collected from various agricultural field soils during crop cultivation in and around Thiruvannamalai, Tamil Nadu for the present analysis is given in Table 1 .

\section{Moisture content of soil samples}

Since the moisture content in soil affects the physiological state of microorganisms and plants, it is extremely important to determine correlations between the soil moisture content and soil microbial activity. In view of the above consideration the $\%$ of moisture content of the individual soil samples were presented in the following table 2. Among the samples analyzed for the moisture content, the groundnut and turmeric field show higher moisture as $26.0 \%$ and $26.3 \%$ respectively. The lowest moisture content was observed in sugarcane and tapioca as $11.0 \%$ and $17.0 \%$ respectively. The waste land soil with parthenium field shows $22.2 \%$ moisture content.

\section{Qualitative analysis of Mycoflora}

The following individual species of fungi were isolated from various samples of soil collected in the present study.

The morphological appearance of different species of fungi growing in Potato Dextrose Agar (PDA) plates were shown in the figures 1, 2, 3, 4, 5 and 6.. Among the soil samples plated in agar plates, the Fig. 3 show only two white non-sporulating fungi which indicates the turmeric soil environment has inhibitory effect of fungi.

\section{Quantitative distribution of individual fungi}

\section{Groundnut field}

The occurrence of individual species of fungi present in soil sample of Groundnut field is presented in Table 3 and Chart 1. 
Fig.1 The growth of fungi from the soil collected from sugarcane field

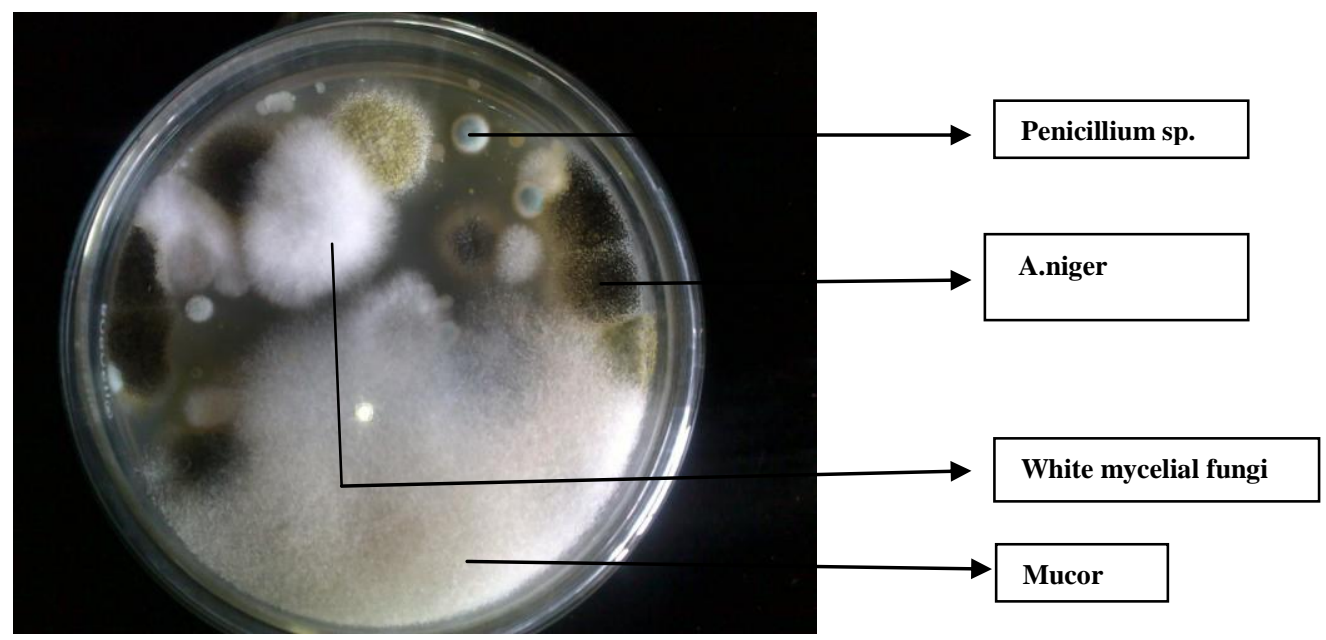

Fig.2 Growth of fungi in soil sample of Tapioca field

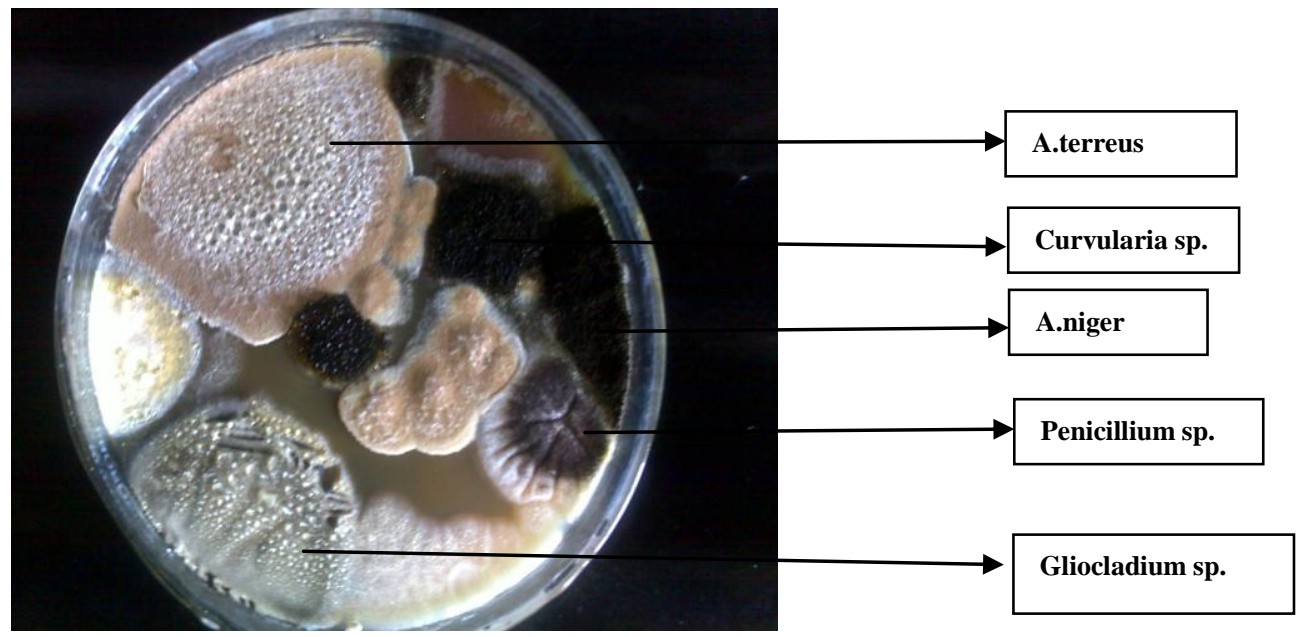

Fig.3 Growth of fungi in soil sample of Turmeric field

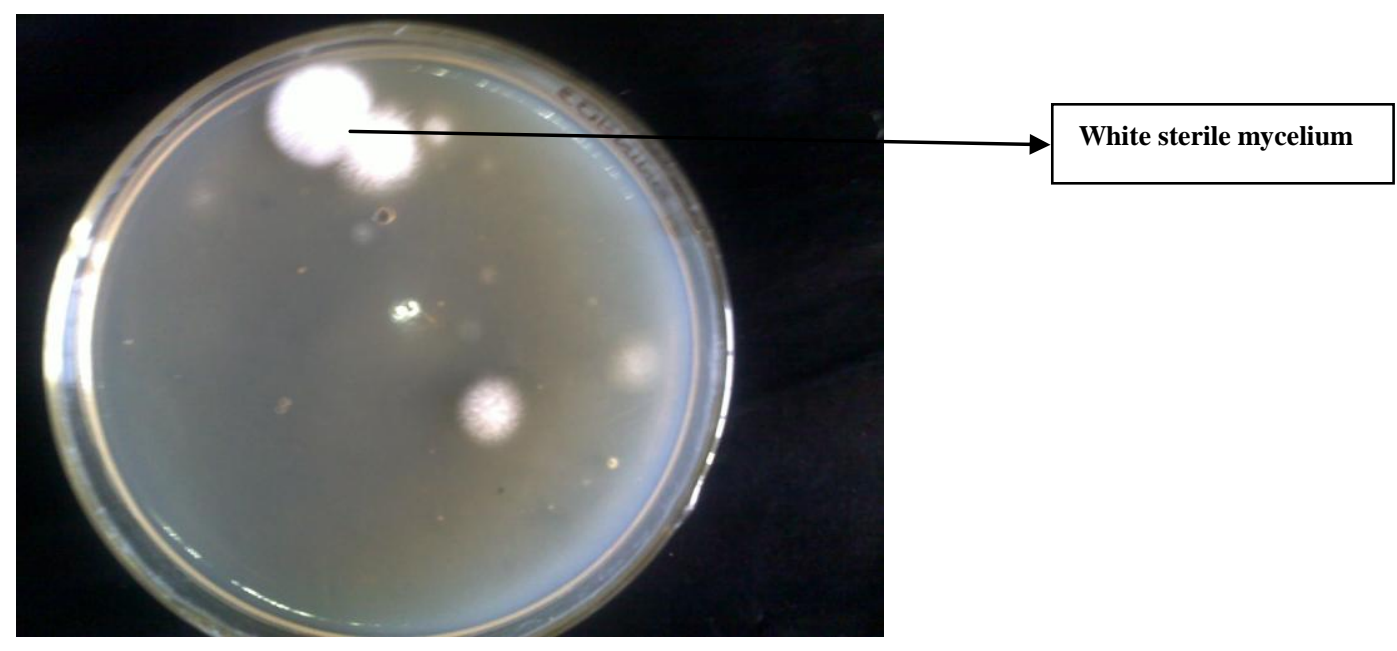


Fig.4 Growth of fungi in soil sample of Plantain field

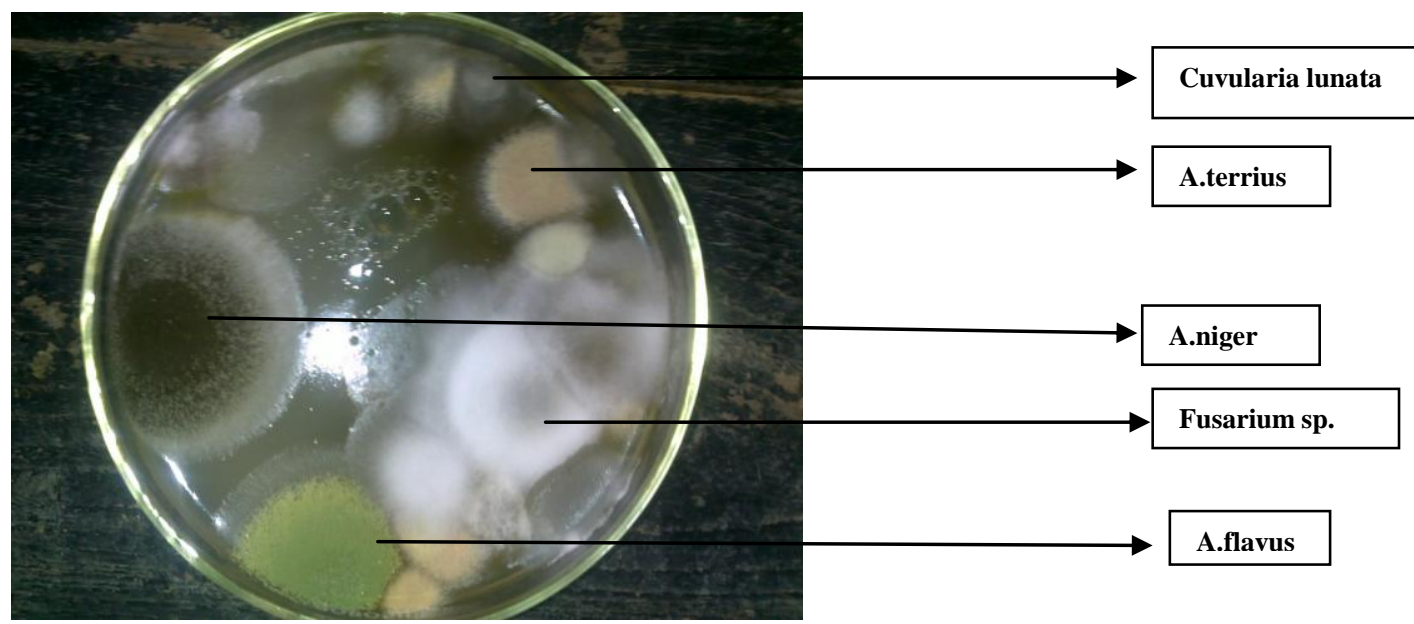

Fig.5 Growth of fungi in soil sample of Groundnut field

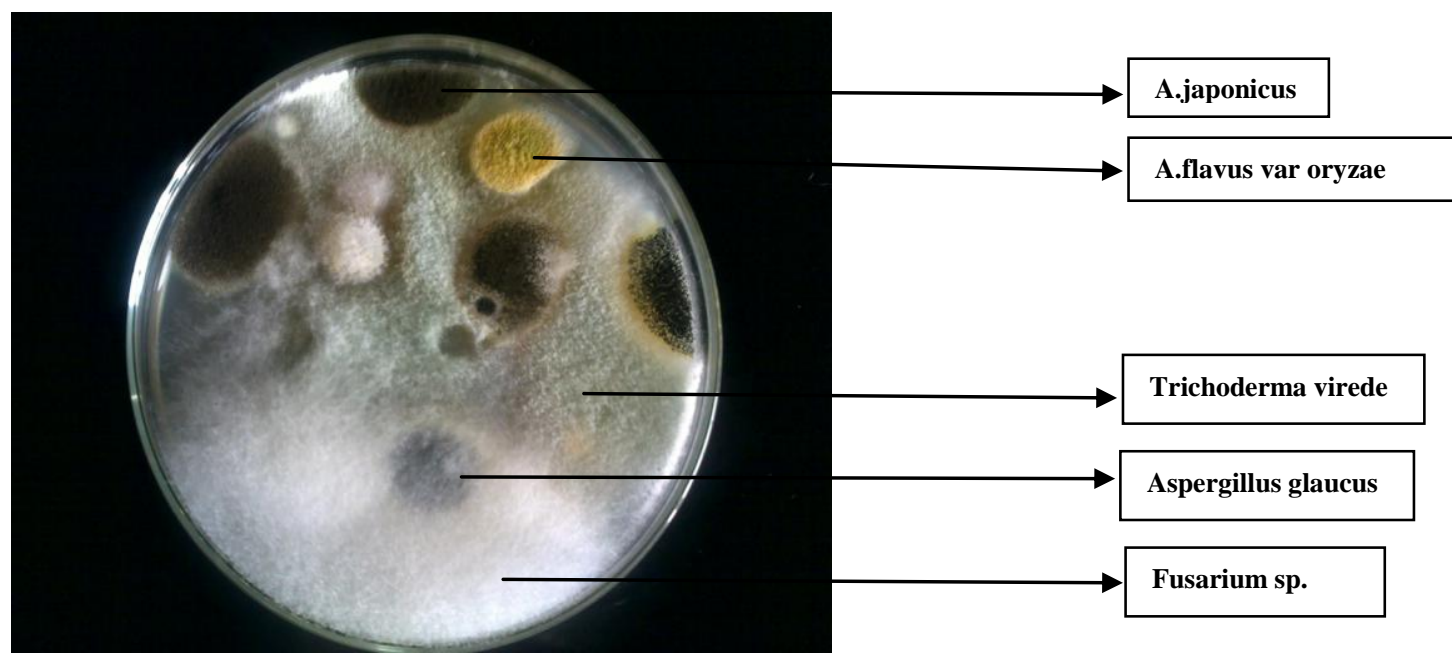

Fig.6 Growth of fungi in soil sample of Parthenium field

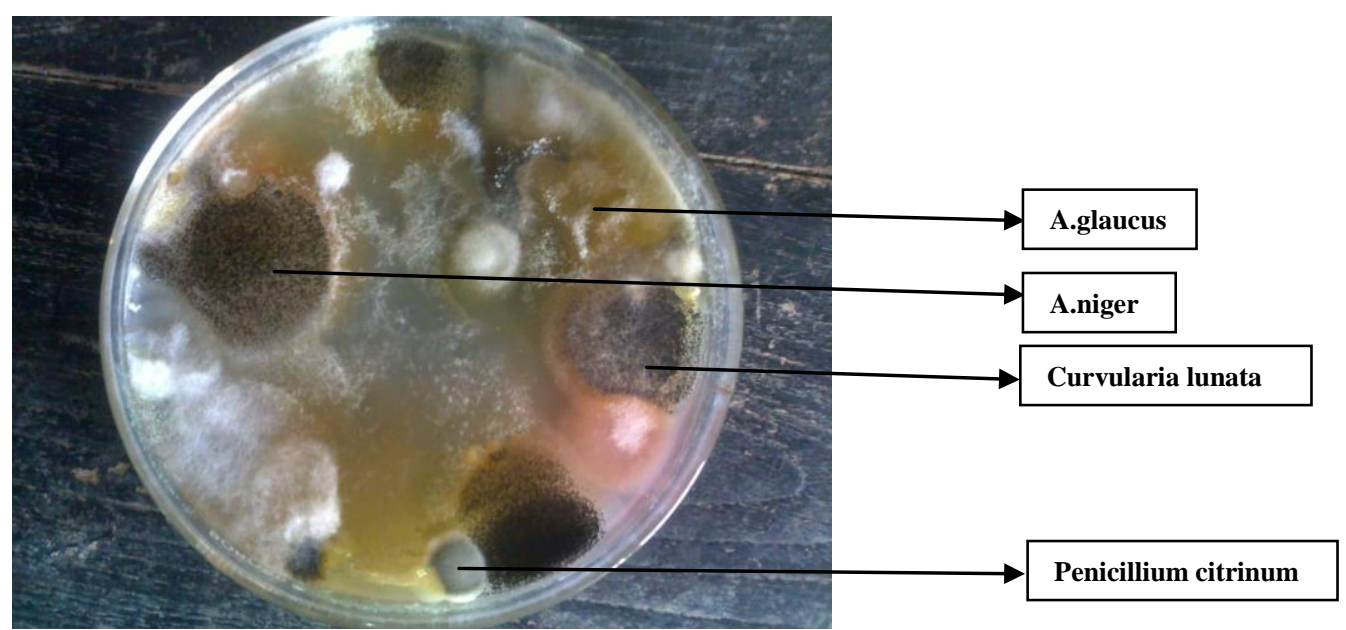


Chart.1 The quantitative occurrence of individual fungi present in soil sample from Groundnut filed

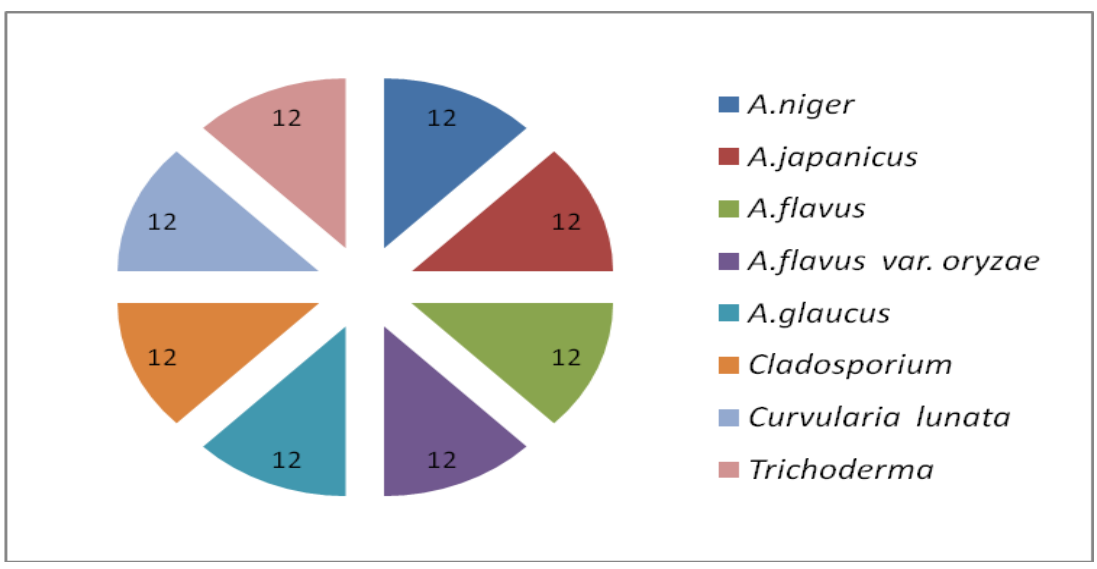

Chart.2 The quantitative occurrence of individual fungi present in soil sample from Sugarcane filed

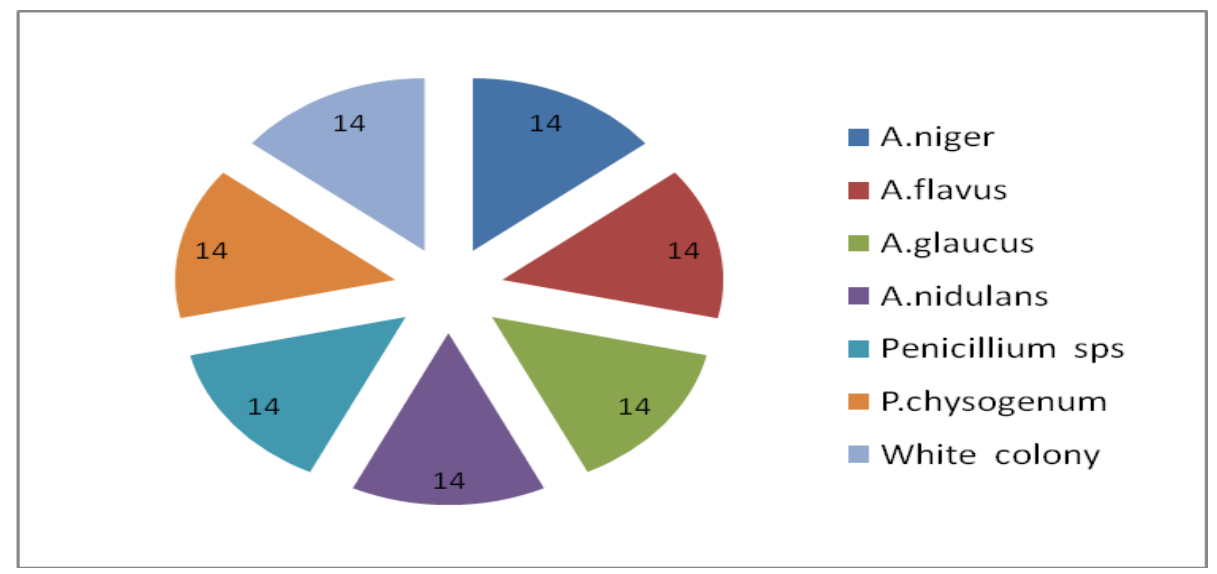

Chart.3 The quantitative occurrence of individual fungi present in soil sample from Turmeric filed

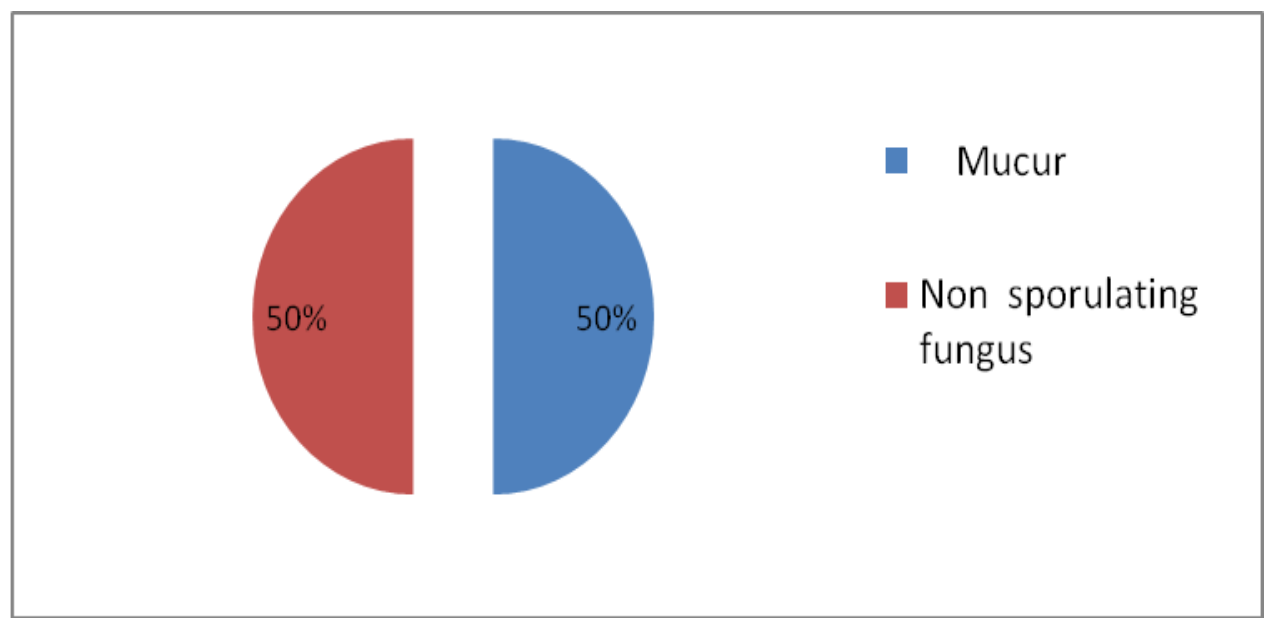


Chart.4 The quantitative occurrence of individual fungi present in soil sample from Plantain field

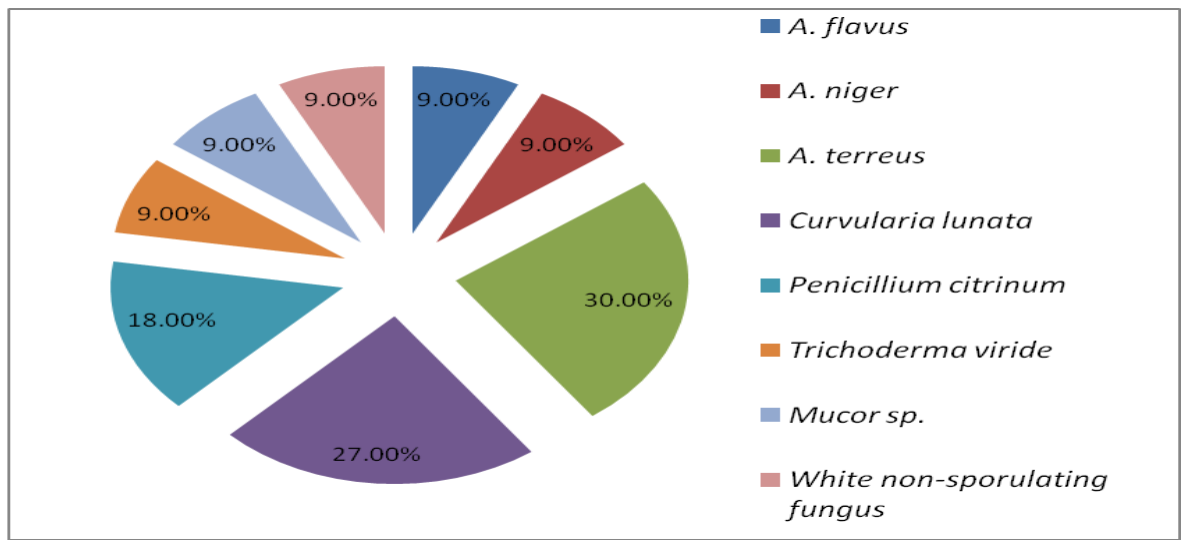

Chart.5 The quantitative occurrence of individual fungi present in soil sample from Tapioca filed

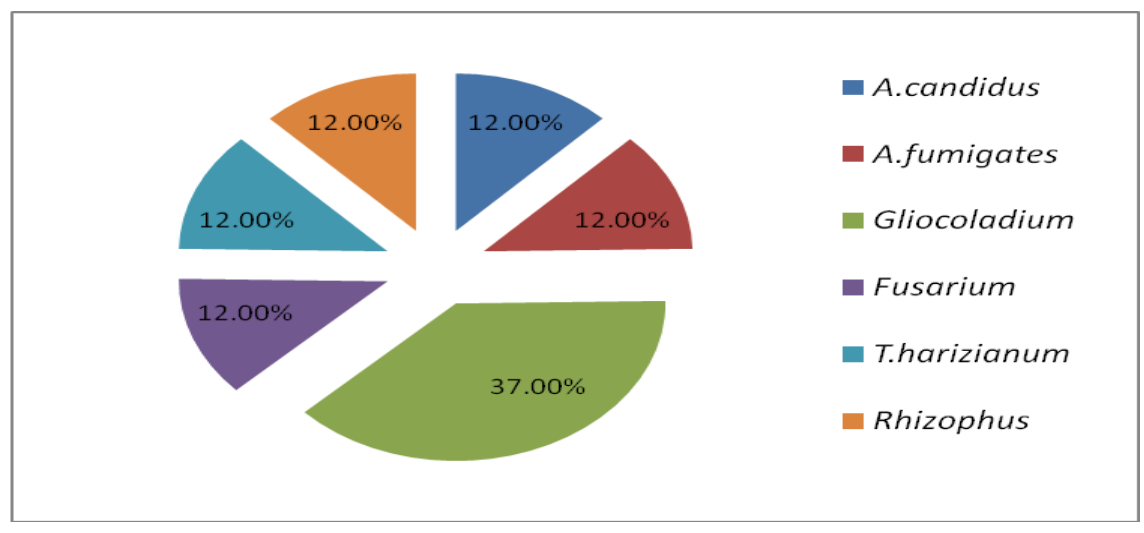

Chart.6 The quantitative occurrence of individual fungi present in soil sample from Parthenium filed

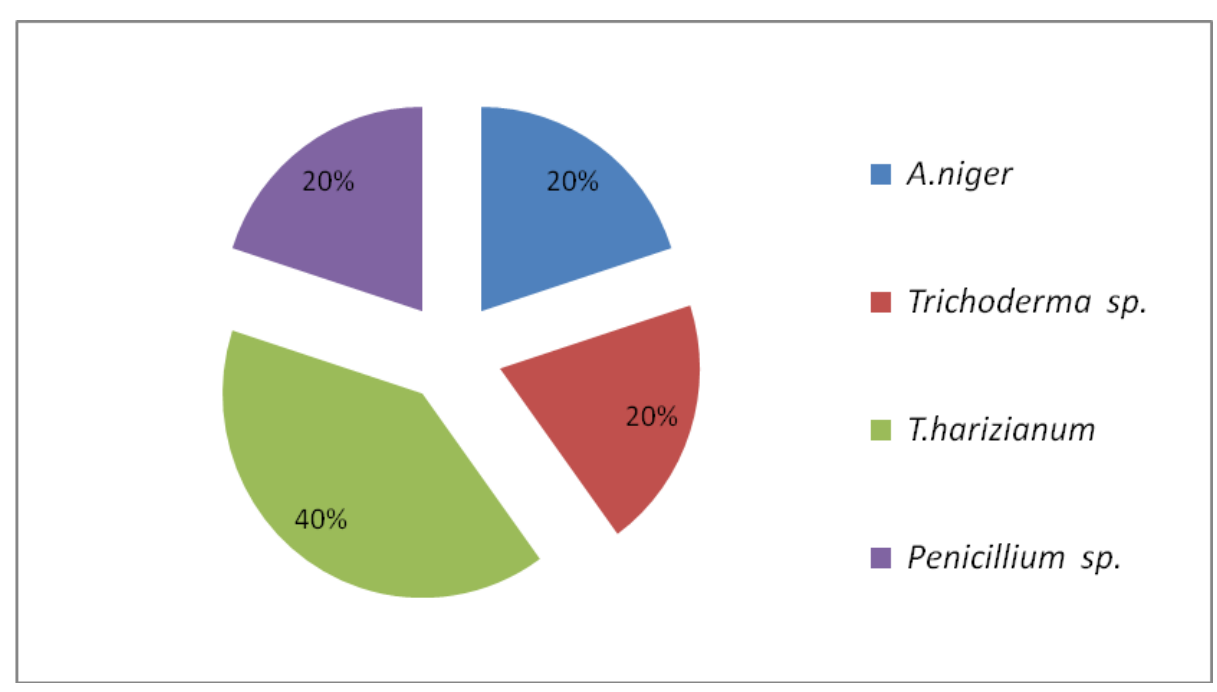


Chart.7 Comparative pattern of Distribution of fungal species in different soil samples

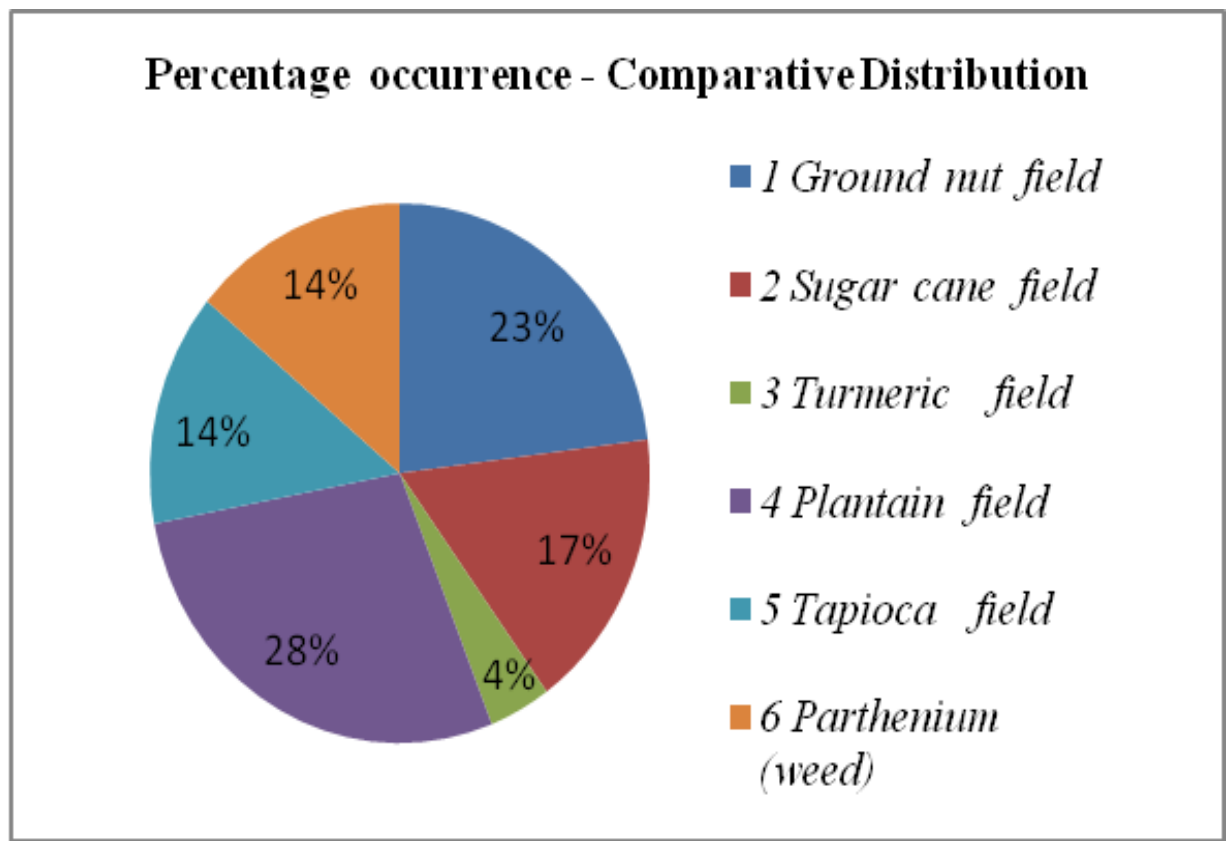

Table.1 Details of soil samples collected from different places of Thiruvannamalai

\begin{tabular}{|c|l|l|l|} 
S. No & $\begin{array}{c}\text { Name of the soil } \\
\text { sample }\end{array}$ & $\begin{array}{c}\text { Harvesting } \\
\text { period of the } \\
\text { crop }\end{array}$ & $\begin{array}{c}\text { Time of collection } \\
\text { (at crop growth) }\end{array}$ \\
\hline $\mathbf{1}$ & Ground nut field & 3 months & $2^{\text {nd }}$ month \\
\hline $\mathbf{2}$ & Sugar cane field & 12 months & $9^{\text {th }}$ month \\
\hline $\mathbf{3}$ & Turmeric field & $6-8$ months & $6^{\text {th }}$ month \\
\hline $\mathbf{4}$ & Plantain field & $10-12$ months & $10^{\text {th }}$ month \\
\hline $\mathbf{5}$ & Tapioca field & $5-6$ months & $5^{\text {th }}$ month \\
\hline $\mathbf{6}$ & Parthenium (weed) & 3 months & 3rd month \\
\hline
\end{tabular}

Table.2 The details of moisture content of various soil samples

\begin{tabular}{|l|l|l|}
\hline S. No & Name of the field soil & $\begin{array}{l}\text { Moisture } \\
\text { content }(\%)\end{array}$ \\
\hline $\mathbf{1}$ & Ground nut & $\mathbf{2 6 . 0}$ \\
\hline $\mathbf{2}$ & Sugarcane & $\mathbf{1 1 . 0}$ \\
\hline $\mathbf{3}$ & Turmeric & $\mathbf{2 6 . 3}$ \\
\hline $\mathbf{4}$ & Plantain & $\mathbf{2 0 . 2}$ \\
\hline $\mathbf{5}$ & Tapioca & $\mathbf{1 7 . 0}$ \\
\hline $\mathbf{6}$ & Parthenium & $\mathbf{2 2 . 2}$ \\
\hline
\end{tabular}


Table.3 The quantitative occurrence of individual fungi present in soil sample from Groundnut filed

\begin{tabular}{|c|c|c|c|}
\hline Sl. No. & $\begin{array}{c}\text { Name of the } \\
\text { Fungi }\end{array}$ & $\begin{array}{c}\text { No of } \\
\text { Colonies }(\mathrm{cfu} / \mathrm{g})\end{array}$ & $\begin{array}{l}\text { Percentage } \\
\text { occurrence }\end{array}$ \\
\hline 1 & niger & 1 & 12 \\
\hline 2 & A.japanicus & 1 & 12 \\
\hline 3 & A. flavus & 1 & 12 \\
\hline 4 & flavus var. oryzae & 1 & 12 \\
\hline 5 & A. $\quad$ glaucus & 1 & 12 \\
\hline 6 & Cladosporium sp. & 1 & 12 \\
\hline 7 & Curvularia lunata & 1 & 12 \\
\hline 8 & Trichoderma sp. & 1 & 12 \\
\hline
\end{tabular}

Table.4 The quantitative occurrence of individual fungi present in soil sample from Sugarcane filed

\begin{tabular}{|l|l|l|l|}
\hline SI. No. & \multicolumn{1}{|c|}{ Name of the fungi } & $\begin{array}{c}\text { No of colonies } \\
\text { (cfu/g) }\end{array}$ & $\begin{array}{c}\text { Percentage } \\
\text { Occurrence }\end{array}$ \\
\hline $\mathbf{1}$ & A.niger & 1 & 14 \\
\hline $\mathbf{2}$ & A.flavus & 1 & 14 \\
\hline $\mathbf{3}$ & A.glaucus & 1 & 14 \\
\hline $\mathbf{4}$ & A.nidulans & 1 & 14 \\
\hline $\mathbf{5}$ & Penicillium $s p$. & 1 & 14 \\
\hline $\mathbf{6}$ & P.chysogenum & 1 & 14 \\
\hline $\mathbf{7}$ & White colony & 1 & 14 \\
\hline
\end{tabular}

Table.5 The quantitative occurrence of individual fungi present in soil sample from Turmeric filed

\begin{tabular}{|l|l|l|l|}
\hline SI.No & Name of the species & $\begin{array}{c}\text { No of } \\
\text { colonies(cfu/g) }\end{array}$ & $\begin{array}{l}\text { Percentage } \\
\text { Occurrence }\end{array}$ \\
\hline $\mathbf{1}$ & Mucor & 1 & 50 \\
\hline $\mathbf{2}$ & Non sporulating fungus & 1 & 50 \\
\hline
\end{tabular}

Table.6 The quantitative occurrence of individual fungi present in soil sample from Plantain field

\begin{tabular}{|c|}
\hline Sl. No. \\
\hline 1 \\
\hline 2 \\
\hline 3 \\
\hline 4 \\
\hline 5 \\
\hline 6 \\
\hline 7 \\
\hline 8 \\
\hline
\end{tabular}
Fungal species

\begin{tabular}{|c|}
\hline No of colonies $(\mathbf{c f u} / \mathbf{g})$ \\
\hline 1 \\
\hline 1 \\
\hline 3 \\
\hline 1 \\
\hline 2 \\
\hline 1 \\
\hline 1 \\
\hline 1
\end{tabular}

Percentage occurrence

A.flavus

A.niger

A.terreus

Curvularia lunata

Penicillium citrinum

Trichoderma viride

Mucor sp.

White non-sporulating fungus 
Table.7 The quantitative occurrence of individual fungi present in soil sample from Tapioca filed

\begin{tabular}{|l|l|l|l|}
\hline Sl.No. & \multicolumn{1}{|c|}{ Fungal species } & No of colonies(cfu/g) & \multicolumn{1}{|c|}{$\begin{array}{c}\text { Percentage } \\
\text { Occurrence }\end{array}$} \\
\hline $\mathbf{1}$ & A.candidus & 1 & 12 \\
\hline $\mathbf{2}$ & A.fumigates & 1 & 12 \\
\hline $\mathbf{3}$ & Gliocoladium & 3 & 37 \\
\hline $\mathbf{4}$ & Fusarium & 1 & 12 \\
\hline $\mathbf{5}$ & T.harizianum & 1 & 12 \\
\hline $\mathbf{6}$ & Rhizophus & 1 & 12 \\
\hline
\end{tabular}

Table.8 The quantitative occurrence of individual fungi present in soil sample from Parthenium filed

\begin{tabular}{|c|l|c|c|}
\hline SI. No. & \multicolumn{1}{|c|}{ Fungal species } & $\begin{array}{c}\text { No of colonies } \\
\text { (cfu/g) }\end{array}$ & $\begin{array}{c}\text { Percentage } \\
\text { Occurrence }\end{array}$ \\
\hline $\mathbf{1}$ & A.niger & 1 & $\mathbf{2 0}$ \\
\hline $\mathbf{2}$ & Trichoderma $s p$. & 1 & $\mathbf{2 0}$ \\
\hline $\mathbf{3}$ & T.harizianum & 2 & $\mathbf{4 0}$ \\
\hline $\mathbf{4}$ & Penicillium $s p$. & $\mathbf{1}$ & $\mathbf{2 0}$ \\
\hline
\end{tabular}

Qualitative analysis of Mycoflora

\begin{tabular}{|r|l|r|l|}
\hline $\mathbf{1}$ & Aspergillus niger & $\mathbf{1 1}$ & P. chrysogenum \\
\hline $\mathbf{2}$ & A. niger var. japonicas & 12 & Penicillium sp. \\
\hline $\mathbf{3}$ & A. flavus & 13 & Mucor sp. \\
\hline $\mathbf{4}$ & A.flavus var oryzae & 14 & Rhizophus sp. \\
\hline $\mathbf{5}$ & A. glaucus var. amsterdomi & 15 & Trichoderma virede \\
\hline 6. & A. nidulans & 16 & T. harzianum \\
\hline $\mathbf{7}$ & A. terreus & 17 & Cladosporium cladosporioides \\
\hline $\mathbf{8 .}$ & A. candidus & 18 & Curvularia lunata \\
\hline 9. & A. fumigates & 19 & Gliocladium sp. \\
\hline 10. Penicillium citrium & 20 & Fusarium sp. \\
\hline
\end{tabular}

The individual species of fungi such as $A$. niger, A. japonicas, A. flavus, A. glaucus, Cladosporium sp., Curvulari lunata were present at equal contribution. The percentage of individual species of fungi is $12 \%$.

\section{Sugarcane field}

The occurrence of individual species of fungi and their percentage distribution were presented in the Table 4 and Chart- 2. The individual species of fungi such as A. niger, A. flavus, A. glaucus, A. nidulans, Pencillium chrysogenum, Pencillium sp., and nonsporulated white colony were present at $14 \%$ level of each fungus.

\section{Turmeric filed}

In Turmeric field, the occurrence of fungi is very less in numbers. The distribution and percentage occurrence of individual species of 
fungi were presented in the Table 5 and Chart 3 . Here, the remarkable finding is only 2 colonies as Mucor sp. and white nonsporulating fungi present in the culture plate.

\section{Plantain filed}

In the plantain field, the soil found with 8 different species of fungi identified as $A$. flavus, A. niger, A. terreus, Curvularia lunata, Pencillium citrinum, Trichoderma virede, Mucor sp., and White non-sporulating fungus at a different percentage of occurrence. The details of fungi are presented in Table 6 and Chart 4.

\section{Tapioca field}

From the study, it was observed that the fungus namely Gliocladium $s p$. is occurred maxium in the Tapioca field as $37 \%$ and other species of fungi such as $A$. candidus, A.fumigatus, Fusarium sp., Trichoderma harzianum and Rhizophus sp. at 12\%. It indicates, either the soil may contain more population with Gliocladium $s p$. or the rhizosphere of tapioca assumed to be having affinity with the particular fungus. The distribution pattern of individual fungi was shown in Table 7 and Chart 5.

\section{Wasteland with Parthenium (weed) soil}

The occurrence of individual species of fungi and their percentage distribution of soil collected form the wasteland mostly grown with Partheniium $s p$. was found with Trichoderma. hariziamum at $40 \%$ followed by A. niger, Trichoderma vilride. and Penicillium sp. with $20 \%$ each. The details were presented in Table 8 and Chart 6.

\section{Comparative pattern of fungi in different field soils}

The occurrence of different species of fungi in soil samples collected from different crop filed is presented in the Chart 7. In order to observe the dominance of individual species of fungi present in different agricultural crop field soil, the percentage contribution was worked out to understand the relationship between the soil environment with and the affinity towards the growth and survival of mycoflora. Here, one can observe that the groundnut filed soil show higher distribution as $23 \%$ and lower percentage of distribution in turmeric filed soil sample. This indicates the rhizosphere environment of turmeric field likely affect the growth and development of fungi as the turmeric has significant effect.

Biodiversity of fungi is essential for any one collecting and/or monitoring any fungi from various sources of environment. Fascinating and beautiful fungi are vital components of nearly all ecosystems and impact of human health and our economy in myriad of ways. Soil microorganisms including Bacteria, Fungi, Algae and Protozoa are existing in very large number in the soil as long as there is a carbon source and other nutrient available. Among the microorganisms, fungi are occurring in smaller population, but they dominate the soil biomass when the soil environment is not influenced by other factors. Therefore the soil consist of different type of micro and macro nutrients which provide a natural environment for the survival of microorganisms. The moisture content in soil affects the physiological state of microorganisms and plants and it is worth mentioning that soil microorganisms are generally well-adaptable to changing air and water conditions in a soil pedon (Walker et al., 2003). Therefore, the correlations between the moisture content and mycoflora of the soil were done and found there is no significant level of affinity towards the soil by fungi.

It was observed from the present study as the fungi occurring in different type of soil samples like groundnut soil, sugar cane soil, plantain soil, Tapioca soil, Turmeric soil and 
Wasteland with Parthenium soil found with $A$. niger var. japonicas, A. flavus, A.flavus var oryzae,, A. glaucs sp.1, A. glaucus sp.2, A.nidulans, A. terreus, A. candidus, A. fumigates, Penicillium citrinum, $P$. chrysogenum, Penicillium sp., Mucor sp., Rhizophus sp., Trichoderma virede, $T$. harzianum, Cladosporium cladosporioides, Curvularia lunata, Gliocladium sp., Fusarium $s p$. and White non sporulating fungus. These results indicates that that the agricultural soil may contain various nutrients which are supporting for the growth and survival of wide variety of fungal species in the soil for prolonged period. The above results are in accordance with various reports, the fungi commonly present in diffferent type of soils found as Aspergillus niger, A. flavus, A. clavatus, A. terreus, Curvularia lunata, Pencillium janthinellum, $P$. citrinum, Rhizopus nigricans, Trichoderma viride, $T$. harzianum, Fusarium. oxysporium, $F$. moniliforme, Mucor, Cladosporium, Verticillium, Acremonium, Chaetomium globosum, Corynespora cassicola, Eurotium chevelari, Botrycis cineea, Helminthosporium sp. etc. (Chirstensen et al., 1962; Deka and Mishra, 1984; Wahid et al., 1997; Saravanakumar and Kaviarasan, 2010,). Prince et al., 2011 investigated the seasonal variations in soil fungal population of traditional sugarcane field in Thanjavur District, Tamilnadu viz Orathanadu and Pattukottai with 49 different species belonging to Phycomycetes and Deteromycetes with dominant species as Aspergillus niger, A.flavus followed by Botrytis cinera, Trichoderma viride, T.harizianum, T.koeningii, T.glaucum, Penicillium chrysogenum and P.citrinum which is similar to our findings.

On analysis of individual soil samples, in the Groundnut field shows A.niger, A.japanicus, A.flavus, A.flavua var oryzae, A.glacus, Cladosporium sp., Cuvularia lunata, and
Trichoderma sp.. are the fungi commonly present in the order of dominance. At the same time the soil samples collected from the sugarcane field shows A.niger, A.flavus, A.glacus amster, A.nidulans, Penicillium sp. are present in significant level. But the mycoflora of the soil samples collected from the Turmeric field shows a unexpected results as very low percentage of fungal colonies with one each of Mucor and other nonsporulating white colony with poor growth. Surprisingly this absence of fungal load in the turmeric field may be due to the excretion of antimicrobial bioactive compounds from the rhizome in the soil environment. This in accordance with earlier scientific reports that indicates the antimicrobial effect of turmeric on various microorganisms. But in the soil mycoflora of tapioca field shows the sole presence of Gliocladium sp. occuring in very high percentage in the culture plates. This may be due versatile nature of fungi present in different crop environment.

In conclusion, the present study shows the versatile nature of fungal biodiversity from different agricultural soil samples with different population density which may be due to there between the soil types, crop cultivation, soil nutrients, soil $\mathrm{pH}$, soil moisture and soil mycoflora. Soil environment of different areas of agricultural field with different crop cultivation was studied to know the relationship of fungal diversity and rhizosphere environment. The interaction between the presence of crop and soil fertility due to manure and pesticide addition and other chemicals present also were interpreted. There is no correlation was found with fungal population and the moisture content of soil samples from different environment. However, there is a antimicrobial effect due to secretion of compounds from plants in the soil environment evidenced from turmeric field 
soil from the present study is interesting and pave the way for future work..

\section{Acknowledgement}

The authors were thankful to Prof. Pandiyan, HOD, Department of Botany and The Principal, Government Arts College, Thiruvannamalai for laboratory facilities and encouragement for the present study.

\section{References}

Al-Nur El-Amin and Abdulmoneim, M.A. Saadabi 2007. Contribution to the knowledge of soil fungi in Sudan Rhizosphere mycoflora of sugarcane at Kenana sugar estate. Int. J. Bot. Vol. 3(1):97-102, ISSN-9700.

Ambikapathy, V., A. Paneerselvam and R. Saravanamuthu 2001. Population of mycoflora in the paddy field of Poondi, Thanjavur District. J. Agri. Sci. Digest 21(3):145-148.

Ambikapathy. V., A. Paneerselvam and R. Chaderasegaran 1994. Intl. J. Geobios news Report, 13:171-174

Barnett, H.L. and B.B. Hunter. 1998. Illustrated Genera of Imperfect Fungi. The American Phytopathological society. APS press, St. Paul, Minnesota, pp 218.

Breuere. A.M., 2004. Functional Ecology, Vol. 17: 516-525.

Carney, K.M., and Maston, P.A., 2006. Micro Ecol., Vol. 52: 226-382.

Christenson. M, W.F. Whittingham and R.O. Novak the soil microfungi of Wet-mesic forest in Southern Wisconsin 1962. J. Mycologia 54: 374-388.

Deka. H.H and R.R. Misra 1984. J. Acta Botanica Indica 12: 180-184.

Ellis, M.B., 1976. More dematiaceous Hyphomyces, Commonwealth Mycological Institute. Pub., Kew, Survey, England.
El-Said, AHM. 2001. Mycotoxins and invertase enzyme of mycoflora of molases in upper Egypt. Pakistan J. of Biological science, 4(11):1386-1389.

Falih. A.M. 1997. The relationship between heavy metal concentratoin and soil mycoflora in the Gizan region. Soudi Arabia. J. Quator Univ sci, 17(1):111119.

Gangawane, L.V. and K.B. Despandande 1972. Microbial Ecology in same forest soils of Marathwada-1, Rhizosphere microfungi of some common trees of Ajanta hills. Marathwada University Journal of science (B) 11:1-4.

Gauri Rane and R.V. Gandhe 2006. Seasonal distribution of soil fungi from forest soils of Jalgaon District, Maharastra. J. Zoos Print Journal 21(9): 2407-2409.

Gray.J. Griffin and Kenneth.H. Garren 1974. Population levels of Aspergillus flavus and the A.niger group in Virginia peanut field soils. J. Phytopathology. 64: 322-325.

Guleri. S., B.S. Bhandari and S. Saxena 2010. Ecology of Rhizosphere and Non Rhizosphere soil mycoflora of forest soils of Dehradun District Uttarakhand., J. International Transactions Applied sciences. Vol. 2, (1): 69-77.

Hackel. E., G. Bachamann and S. Boltenstern 2000. Zechmeister, Phyton, 48: 83-90.

Jayalakshmi. C. and V. Valluvaparidasan 2010. Parthenium infested soil microbes. Distribution of soil microorganisms in the Parthenium weed insfested soil of Tamil Nadu. Journal of Biopesticites, 3(30:523-525.

Johnson. L.F., E.A. Gurl., J.H. Bond., and H.A. Fribourg 1960. Methods for studying soil Mycoflora. Plant Diseases Relationships. Burgess publishing co. Minneapolis. 179pp.

Madhan Raj. P., S. Manorajan., N. Nadimuthu and A. Paneer Selvam, 2010. J. Advances in Applied Science Research, 
Vol. 1(3):160-167.

Mahmood Khalid, Wei-jun Yang, Nazir kishwar, Zahid Iqbal Rajput, and Abdullah G. Arijo., 2006. J. of Zhejiang Univ Science B 7(6):459-466.

Manimegalai.V, V. Ambigapathy and A. Paneerselvam, 2011. Population dynamics of soil mycoflora in the paddy field of Thanjavur District, Tamil Nadu. Europian Journal of Experimental Biology, 1(3):14-19.

Manoharachary, C., VRT. Reddy and U. Prasad. 1990. Distribution and phenology of soil fungi supporting forest vagitation. J. Geophytology, 20(2): 58-70.

Moallaei. H, F. Zaini, M. Pihet, M. Mahmoudi and J. Hashemi., 2006. Isolation of Keratinophitic Fungi from soil samples of forests and farm yards. Iranian. J. Publ Health., 35(4) 62-69.

Prince, L., P. Samuel., P. Prabagaran., R. Mahalingam 2011. An Investigation of the soil mycoflora in sugarcane field of Tanjavur District-Tamil Nadu.Europian Journal of Experimental Biology, 192):132-138.

Raper. K.B and D.I. Fennell 1965. The genus Aspergillus, Baltimore: The Williams and Wilkins co., 686pp.

Raper. K.B. and C. Thom., 1949. A manual Penicillia Baltimose: The Willams and Wilkins co, 875pp

Reddy. V.N., P. Prakash and C. Manoharachary 1987. Fungi-stasis in forest soil using the dominant soil
fungi.J.Biome 2(1):126-128.

Saksena, R.K., Krishna Nand and A.K. Sarbhoy 1967. Ecology of the siol fungi of Uttarpradesh-2., soils of Himalayan forests and their Micro-fungi. J. Proceedings of National institute of science India 33B (34):144-153.

Saravanakumar. K., and V. Kaviyarasan 2010. Seasonal distribution of soil fungi and chemical properties of montane wet temperate forest types of Tamil Nadu.African journal of plant science vol.4(6), pp.190-196.

Sudarma, I.M, Sudirman Denpasar Bali, Suprapta, D. N, 2011. Diversity of soil microorganisms in banana habitats with and without Fusarium wilt symptom, AGRIS, Vol. 17(1):147 - 159.

Trinci, A.P., 1969. J. Gen. Microbial., 57:1124.

Von Arx, J.A. 1974. The genera of fungi sporulating in pure culture $2^{\text {nd }}$ edn., Vaduz Germany. A.R. Ganter verlag. K.G.FL- 9490, 375pp.

Wahid. O.A., F. Moustafa, and M.E. Ibrahim 1997. Soil mycoflra in tomato fields short communication. J. Mycoscience 38:237-241.

Waksman, S. 1922. A method of counting the number of fungi in the soil J. Bact., 7: 339-117.

Walker T.S., Bais H.P., Grotewold E., Vivanco J.M. 2003. Root exudation and rhizosphere biology. Plant Physiology, 132: 44-51.

Warcup. J.H., 1950. Nature, Vol. 117-118.

\section{How to cite this article:}

Jayaraman P., S. Shalini, K. Saraswathi, K. Vadamalai and Logambal R. 2018. Comparative Studies on Fungal Biodiversity of agricultural field soil from Thiruvannamalai District, Tamil Nadu, India. Int.J.Curr.Microbiol.App.Sci. 7(07): 4259-4273.

doi: https://doi.org/10.20546/ijcmas.2018.707.497 